aware of, met with in England, and has not been alluded to as a probable native in any of our local or general floras.

"It was first noticed in July of last year (1854), by Mrs. Anderton Smith, then staying at Tedstone Rectory, and other specimens were afterwards gathered by her husband, who communicated with me on the subject, and indicated the place where Mrs. Smith first gathered the plant. The locality has quite a subalpine aspect, the Sapey brook there running in a deep glen shadowed on all sides by lofty trees, and near the spot a little water-fall gurgles over the massive sandstore rocks. It was the felling of some of these trees that brought the plant to light. I have also to mention another locality for the Neottia or Spiranthes astivalis, hitherto, I believe, only found in England in the New Forest, Hampshire; but the last autumn a specimen of the Spiranthes astivalis was shown to me, which was gathered by Mr. George Jordan of Bewdley, on the confines of the great bog in Wyne Forest, Worcestershire. I have been careful to examine the plant gathered by Mr. Jordan, and to visit the spot where it was found, so that the information may be relied on, and thus the range of the Spiranthes estivalis is extended in England. This it may be interesting to note.

"The enclosed specimen can be exhibited at the next Meeting of the Society, if the plant has not been previously brought before their notice as a native of Britain. It is the only one I at present possess; but if the Linnean Society has not a British specimen in their collection and you think it may be any way advantageous to botanical science, or be useful for metropolitan botanists to examine, I will with pleasure permit the retention of it for the Society. Otherwise please return it to me at your leisure after it has been examined.

"R. Kippist, Esq."

"I remain, my dear Sir, yours very truly. "Edwin Lees."

The specimen of Epipogium, which (in compliance with Mr. Lees' kind permission) has been placed in the herbarium of the Society, is stated on the ticket to have been "gathered in a woody dingle on the banks of Sapey Brook, Tedstone, Herefordshire, about a mile and a half south of Clifton-on-Teme, Worcestershire; July 1854."

\title{
MISCELI.ANEOUS.
}

Sibbald's Drawings of Scottish Animals.

By the late Dr. George Johnston.

There is a small quarto volume of original drawings with the title "Piscium et Aquatilium Icones, a Joanne Alexandro ad vivum depicta. Anno Domini M.Dcc.vir," preserved in the Library of the Royal College of Physicians of Edinburgh. The drawings were undoubtedly. made for Sir Robert Sibbald, and a few 
of them have been engraved to illustrate his book on Whales, and his Natural History of Scotland. On the inside of the board of the volume there is written-" Hic liber olim viri docti D. Roberti Sibbaldi Eq. Aur. fuit, et multorum variorum apud nos piscium icones continet." The title is written within a square border, very neatly ornamented. In the centre of the top there is a clam-shell with a figure of Neptune, his trident, and horses ; and on each side a classical Dolphin. To the right, a figure of the Sepia is suspended over an upright figure of the Loligo sagittata, with a Crab between; and on the left, the Sturgeon and the Tusk make the border, with the Turritella terebra as a piece of separation.

Folio i. A characteristic figure of the Scad or Horse-Mackerel. Fol. ii. "Piscis in lacu Mabano seu vandosus ;" and "a Whale cast in at Rosyth castle." The Vendace is very unlike the figure of that fish in Yarrell; nor can I identify the whale with any figured in Bell's work on the Mammalia. It appears to be a species of Beluga.Fol. iii. Balænoptera Physalus.-Fol. iv. "A Sperma Ceti Whale." Two figures, viz. a side and a back view. There is written on the paper-" Whale at Moryfurth, Feb. 23, 1703. Side, but it did lay halfe vpon the side that one Ey and a little of the bellie was sanded. 57 foots long, and 56 round. booth under and all the skin blackish blew werie smooth and as thick as a bull's and all white fat within and nixt the skin."-Fol. iv. A rude figure of Coronula diadema: a better figure of the Vendace : and "a horse markrett"-which is something I cannot decipher.-Fol. v. A whale cast in at a place which is illegible. The whale is Balænoptera Physalus, and is about 50 feet long.-Fol. vi. Probably a species of Hyperoodon. It is called a North-Caper.-Fol. vii. Fig. sup. Scorpio marinus nostras = the longspined Cottus, Yarrell. Fig. med. Galeus lævis = Acanthias vulgaris or Dog-Fish. Fig. inf. Cataphractus nostras=Aspidophorus europæus.-Fol. viii. A repetition of the figure of the Beluga?-Fol. ix. Fig. 1. The Cat-fish. (2) Gymnetrus Banksii! (3) Galeus nostras =The Dog-fish. (4) Gobius maculis undatis nostras=the unctuous Sucker. (5) Aculeatus marinus major nostras=the Fifteen-spined Stickleback.-Fol.x. A good figure, and appears to represent the Cook Wrasse of Yarrell.-Fol. xi. The Hiatula $=$ the Ballan Wrasse. -Fol. xii. The Bonnet Flooke. This is the Holibut.-Fol. xiii. A very rude and unfinished figure of a "Salmon Stour"? "taken in Sanda in Orkney." The figure is one of the Tunny. There is, on the same folio, the figure of a Tusk without the head, as it is salted. -Fol. xiv. Teeth of the Spermaceti Whale- " Dentes Balenæ macrocephalæ."-Fol. xv. "Loligo," viz. L. media ; and Raia vulgaris = the Common Skate.-Fol. xvi. "Polypus nostras," viz.=Eledone ventricosa.-Fol. xvii. "Sepia nostras" = Sepia officinalis. Both this and the preceding are excellent figures.-Fol. xviii. Loligo sagittata: good.-Fol. xix. A Fossil Nautilus.-Fol. xx. Fossil Nautilus, two species.-Fol. xxi. "Vulva marina, supina fascies" =an Ascidia. "Favus marinus"-The ovisacs of the Fusus antiquus on a stone covered with a Serpula.-Fol. xxii. "The Harper Crab" = Hyas Ann. \& Mag. N.Hist. Ser. 2. Vol. xvi. 
araneus. "A shore Crab," but it is really Portunus depurator.Fol.xxiii. Fig. sup. Perhaps Nymphon giganteum. Fig.med. "Cancer araneus" = Stenorynchus Phalangium. Fig. inf. The Common Crab. -Fol. xxiv. "Scolopendra marina nostras" =Aphrodite aculeata.Fol. xxv." Loligo nostras"=L. sagittata.-Fol. xxvi. "The Lugg" =Arenicola piscatorum. "Urtica rarior sphæricus," a species of Medusa unknown to me--Fol. xxvii. Four unfinished sketches of a Medusa, probably the M. cruciata ; and three equally rude figures of Lobularia digitata.-Fol. xxviii. The claws of the Norway Lobster (Nephrops norvegicus); and a " chela Astaci monstrosa."-Fol. xxix. "Canis carchariæ Icon rudior"-so rude as to be beyond specific identification- "Stella echinata" = Ophiocoma rosula.-Fol. xxx. "Gurnadus griseus" = the Grey Gurnard.-Fol. xxxi. The Tunny : a good figure.-Fol. xxxii. The Tusk: a finished drawing.Fol. xxxiii. "Gurnardus griseus"- the Grey Gurnard again.Fol, xxxiv. "Trachurus"-viz. the Horse-Mackerel.-Fol. xxxv. A figure probably of the Cook Wrasse.

The only other figures are copies of those which have been engraved for the Scotiæ Prod. Nat. Hist. and for Sibbald's other works, more especially his little volume on Whales.

\section{Clausilia rolphir.}

Some of the "new localities" for British plants and shells, discovered by the Rev. W. H. Hawker and given in the last Number of the 'Annals' (p. 212), are so remarkable, that I was glad to see one which I could confirm from personal observation; viz. the station for Clausilia Rolphii (plicatula, Drap.) in Ashford Woods, where I met with it fifteen years ago, when collecting with Mr. Wm. Harris, F.G.S., of Charing.-S. P. WoodWARD,

\section{HELIX ASPERSA.}

A curious specimen of the common Garden Snail has been sent me by Miss $\mathrm{A}$. Hodgson of Ulverstone. It is an adult shell with a second, half-grown individual, fixed to its spire and partly imbedded in the suture of the body-whorl. The winter door (epiphragm) remains in the exposed part of the small shell's aperture, showing that it had died during the first hybernation, whilst its neighbour had survived, and not getting free from the incubus of the empty house of the deceased, had partially enveloped it in the course of its growth to maturity.-S. P. WooDWARD.

\section{Descriptions of some New Species of Birds. \\ By the Viscount Du Bus de Gisignies.}

1. Vireosylvia frenata. V. supra flavido-cinerea; pileo pure cinereo; superciliis ad nucham productis et genis dilute fulvescentibus ; subtus albida; hypochondriis dilute flavido-cinerascentibus; gula utrinque stria atra a basi mandibulæ descendente marginata; remigibus 


\section{$2 \mathrm{BHL}$ Biodiversity Heritage Library}

Johnston, George. 1855. "Sibbald's drawings of Scottish animals." The Annals and magazine of natural history; zoology, botany, and geology 16, 296-298. https://doi.org/10.1080/037454809495534.

View This Item Online: https://www.biodiversitylibrary.org/item/19432

DOI: https://doi.org/10.1080/037454809495534

Permalink: https://www.biodiversitylibrary.org/partpdf/30102

\section{Holding Institution}

Natural History Museum Library, London

\section{Sponsored by}

Natural History Museum Library, London

\section{Copyright \& Reuse}

Copyright Status: Public domain. The BHL considers that this work is no longer under copyright protection.

This document was created from content at the Biodiversity Heritage Library, the world's largest open access digital library for biodiversity literature and archives. Visit BHL at https://www.biodiversitylibrary.org. 